\title{
Intracranial subdural hematoma after unintended durotomy during spine surgery
}

\author{
[Un hématome sous-dural intracrânien causé par la durotomie involontaire lors \\ d'une opération à la colonne vertébrale]
}

Chueng-He Lu MD, Shung-Tai Ho MD, Shang-Shung Kong MD, Chen-Hwan Cherng MD DMSC, Chih-Shung Wong MD PhD

Purpose: To report a case of intracranial subdural hematoma occurring after a spinal dural tear that was made unintentionally during the course of a posterior laminectomy and spinal fusion at the $\mathrm{L}_{5}-\mathrm{S}$, level. The possible physiopathological mechanisms are discussed.

Clinical features: On the fourth postoperative day, a 59-yr-old woman displayed persistent headache following unintended durotomy during spine implant revision. Perioperative blood loss was $2840 \mathrm{~mL}$ and intravascular replacement was about $3000 \mathrm{~mL}$. She was hydrated with iv fluids and treated with non-steroidal antiinflammatory drugs. The symptoms improved but persisted. With the aggravation of the headache complicated with unconsciousness and the appearance of focal neurological signs on the eighth day, a computed tomography was obtained and revealed a right subdural hematoma. Following surgical drainage, the patient made an uneventful recovery.

Conclusion: This case reminds us that subdural hematoma formation can complicate durotomy during spine surgery. Neurological deterioration in the postoperative period should prompt clinicians to rule out the diagnosis and intervene rapidly as appropriate.

Objectif : Rapporter un cas d'hématome sous-dural intracrânien survenu après une brèche involontaire de la dure-mère spinale au cours d'une laminectomie postérieure et d'une arthrodèse au niveau L5-SI. Les mécanismes physiopathologiques possibles sont discutés.

Éléments cliniques : Au quatrième jour postopératoire, une femme de 59 ans présentait des céphalées persistantes après une durotomie involontaire survenue pendant la reprise d'un implant rachidien. La perte sanguine périopératoire a été de $2840 \mathrm{~mL}$ et le remplissage vasculaire d'environ $3000 \mathrm{~mL}$. La patiente a été hydratée avec des liquides iv et traitée par des anti-inflammatoires non stéroïdiens. Ce qui a diminué les symptômes sans les éliminer. Étant donné l'aggravation des céphalées, compliquées d'inconscience, et de l'apparition de signes neurologiques le huitième jour, on a demandé un examen tomodensitométrique qui a révélé un hématome sous-dural droit. Après le drainage chirurgical, la patiente s'est bien rétablie.

Conclusion: Ce cas rappelle que la formation d'un hématome sousdural peut compliquer la durotomie survenant pendant une opération à la colonne vertébrale. La détérioration neurologique postopératoire incite à poser rapidement le diagnostic et à intervenir en conséquence.

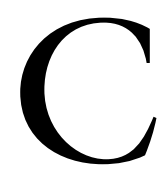

EREBROSPINAL fluid (CSF) leakage induced headache is often noted after spinal anesthesia and unintentional dural puncture during epidural anesthesia and results from traction on pain-sensitive structures within the cranium. ${ }^{1-3}$ Unintended durotomy is one of the most common complications encountered during spine surgery. ${ }^{4}$ An accidental dural tear allows a continued leakage of CSF with caudal displacement of the brain. It may further tear the intracranial subdural veins and result in subdural hematoma formation. The present report describes a case of intracranial subdural hematoma formation following accidental durotomy during spine surgery consisting of posterior laminectomy with variable screw placement stabilization. Here, we emphasize the importance of early diagnosis and appropriate treatment of this serious complication.

Case report

A 59-yr-old woman (height $158 \mathrm{~cm}$, weight $62 \mathrm{~kg}$ ) was admitted with a diagnosis of failure of the spine

From the Department of Anesthesiology, Tri-Service General Hospital and National Defense Medical Center, Taipei, Taiwan.

Address correspondence to: Dr. Chih-Shung Wong, Department of Anesthesiology, Tri-Service General Hospital and National Defense Medical Center, \#325, Chengkung Road, Section 2, Nei-Hu, 114, Taipei, Taiwan, R.O.C. Phone: +886 (2) 87927126; Fax: +886 (2) 87927127; E-mail: w82556@ndmctsgh.edu.tw

Accepted for publication August 27, 2001.

Revision accepted September 27, 2001. 
instrumentation over $L_{5}-S_{1}$ and surgical revision was planned. Hypertension and diabetes mellitus had been noted for years and were under regular medical treatment. All laboratory data including coagulation status were within normal limits on admission. Preoperative blood pressure was $150 / 80 \mathrm{mmHg}$ with heart rate around 90 beats. $\mathrm{min}^{-1}$. Anesthesia was induced with thiopentone $300 \mathrm{mg}$ and fentanyl $100 \mu \mathrm{g}$ and tracheal intubation facilitated by succinylcholine $80 \mathrm{mg}$. Anesthesia was maintained with isoflurane $4-5 \%$ in $\mathrm{O}_{2}$ $\left(300 \mathrm{~mL} \cdot \mathrm{min}^{-1}\right)$. The arterial hemoglobin $\mathrm{O}_{2}$ saturation $\left(\mathrm{SpO}_{2}\right)$ remained between $98-99 \%$ during surgery. The patient was ventilated mechanically and end-tidal $\mathrm{CO}_{2}$ maintained between $35-40 \mathrm{mmHg}$.

The patient underwent posterior laminectomy for $\mathrm{L}_{5}$ to $\mathrm{S}_{1}$ fusion with autologous iliac bone graft and stabilization with a variable screw placement system. A dural tear was identified during the procedure. Primary closure was performed with 4-O and 5-O silk, and gelfoam was used to cover the repair site. A subfascial suction drain was placed and the wound closed layer by layer. Total perioperative blood loss was $2840 \mathrm{~mL}$. Total fluid replacement included four units of packed red blood cell $(125 \mathrm{~mL}$ per unit; total $500 \mathrm{~mL})$, six units of whole blood $(250 \mathrm{~mL}$ per unit; total $1500 \mathrm{~mL}$ ) and $3000 \mathrm{~mL}$ of crystalloids during the operation.

The patient denied the presence of headache during the first three days after surgery. On the fourth day, the patient developed a persistent, throbbing right retroorbital and right hemicranial headache with a mild neck stiffness. However, her vital signs, including temperature, were within normal limits and no abnormalities were found on physical or neurologic examination. These symptoms were first thought to be due to CSF leakage, thus she was hydrated with $1000 \mathrm{~mL}$ iv fluids and treated with non-steroidal anti-inflammatory drugs (NSAIDs). The symptoms improved but did not disappear. On the seventh postoperative day, the patient complained of severe headache with nausea and vomiting that was not related to position changes. Moreover, general weakness and loss of appetite were also noted. Again, her medical history revealed no previous head trauma, coagulation abnormalities, or neurologic disorders. Once more, iv fluids and NSAIDs were given, and resulted in some improvement. Two days later, the patient's condition deteriorated further and she became drowsy. Neurological examination revealed a left hemiparesis with left Babinski's sign and the Glascow coma scale was 9. Emergent computed tomography (CT) scan showed a large subdural hematoma over the right convexity with midline shift and marked subfascial herniation. Emergent right-parietal burr-hole with drainage was performed under gen- eral anesthesia without any complication. This second operation relieved the patient's symptoms, and she was discharged 14 days later without any neurological sequelae.

Discussion

Dural tear is one of the most common complications of spine surgery, with a prevalence of 1 to $17 \%$ in series reporting from 5 to 450 patients. ${ }^{5-8}$ The causes of dural tear during primary operation include eroded or thin dura, dura adhesion, and redundant dura in patients diagnosed with a tight spinal stenosis. It is particularly prevalent in patients who have epidural fibrosis and scar tissue adherent to the dura during revision of spine surgery. ${ }^{4}$ The operative technique plays a key role in avoiding injury to the dural tissue.

Intracranial subdural hematoma formation has been reported after dural tear with persistent leakage of CSF. ${ }^{9}$ However, the exact pathophysiological mechanism is not known. One possible explanation is that CSF leakage reduces intraspinal as well as intracranial pressure. The altered CSF dynamics may result in a caudally-directed movement of the spinal cord and brain, which in turn stretches the pain-sensitive structures, dura, cranial nerves and bridging veins. ${ }^{10}$ Cerebral veins drain into dural sinuses that are adherent to the inner table of the skull. Many structural features, based mainly on electron microscopic data, imply that bridging veins are more fragile in the subdural portion than in the subarachnoid space. ${ }^{11}$ Therefore, any traction exerted on the bridging veins will rupture at their weakest point in the subdural space. It is presumed that CSF leaked via a dural fistula created by accidental durotomy may cause a caudal displacement of the brain, which in turn pulls and tears the bridging vessels, and results in a subdural hemorrhage and hematoma formation. The symptoms of such intracranial hematoma are persistent headache, sometimes accompanied with other symptoms and signs such as vomiting and a feeling of unreality. In many cases, somnolence, confusion, even coma are the symptoms that first lead to the diagnosis. A CT-scan will confirm the diagnosis and must be performed as early as it is suspected.

Dehydration may further increase the risk of imbalance between CSF loss and production. ${ }^{12}$ Dehydration induced reduction of brain volume could lead to subdural hemorrhage. Low intracranial pressure, as a result of perioperative dehydration, promotes excessive blood congestion in the bridging veins with consequent dilatation and increasing tension of the vessels, which are further stretched by a downward displacement of the brain, and consequently more vulnerable to the 
movement of the brain within its coverings due to the decreased cerebral volume. ${ }^{13}$ In the present case, total intraoperative blood loss was $2840 \mathrm{~mL}$, fluid replacement totalled $5500 \mathrm{~mL}$, ruling out dehydration. Trivial head injury may also lead to a subdural hematoma in elderly patients and spontaneous hematoma is also observed in anticoagulated patients. ${ }^{14}$ In the present case, the patient neither had a history of head injury nor received anticoagulants and the postoperative coagulation status was within normal limits.

In summary, a 59-yr-old woman developed an intracranial subdural hematoma ten days after unintended durotomy during revision spine surgery. This case reminds us that subdural hematoma formation can complicate durotomy during spine surgery. Neurological deterioration in the postoperative period should prompt clinicians to rule out the diagnosis and intervene rapidly as appropriate.

\section{References}

1 Bjärnhall $M$, Ekseth K, Boström S, Vegfors $M$. Intracranial subdural haematoma - a rare complication following spinal anaesthesia. Acta Anaesthesiol Scand 1996; 40: 1249-51.

2 Baldwin LN, Galizia EJ. Bilateral subdural haematomas: a rare diagnostic dilemma following spinal anaesthesia. Anaesth Intensive Care 1993; 21: 120-1.

3 Macon ME, Armstrong L, Brown EM. Subdural hematoma following spinal anesthesia. Anesthesiology 1990; 72: 380-1.

4 Wang JC, Boblman HH, Riew KD. Dural tears secondary to operations on the lumbar spine.

Management and results after a two-year-minimum follow-up of eighty-eight patients. J Bone Joint Surg 1998; 80-A: 1728-32.

5 Eismont FJ, Wiesel SW, Rothman RH. Treatment of dural tears associated with spinal surgery. J Bone Joint Surg 1981; 63-A: 1132-6.

6 Finnegan WJ, Fenlin JM, Marvel JP, Nardini RJ, Rothman $R H$. Results of surgical intervention in the symptomatic multiply-operated back patient. Analysis of sixty-seven cases followed for three to seven years. J Bone Joint Surg 1979; 61-A: 1077-82.

7 Jones AAM, Stambough JL, Balderston RA, Rothman $R H$, Booth RE Jr. Long-term results of lumbar spine surgery complicated by unintended incidental durotomy. Spine 1989; 14: 443-6.

8 Kitchel SH, Eismont FJ, Green BA. Closed subarachnoid drainage for management of cerebrospinal fluid leakage after an operation on the spine. J Bone Joint Surg 1989; 71-A: 984-7.

9 Sköldefors EK, Olofsson CI. Intracranial subdural haematoma complicates accidental dural tap during labour. Eur J Obstet Gynecol 1998; 81: 119-21.

10 Lay CL, Campbell JK, Mokri B. Low cerebrospinal fluid pressure headache. In: Goadsby PJ, Silberstein SD (Eds.). Headache. Boston: Butterworth-Heinemann, 1997: 355-67.

11 Yamashima T, Friede RL. Why do bridging veins rupture into the virtual subdural space? J Neurol Neurosurg Psychiatry 1984; 47: 121-7.

12 Chodobski A, Szmydynger-Chodobska J, McKinley MJ. Cerebrospinal fluid formation and absorption in dehydrated sheep. Am J Physiol 1998; 275 : F235-8.

13 Lu $\Upsilon$-H, Liaw W-J, Chang W-T, Wong C-S, Ho S-T. Stroke-like complication after abdominal surgery: a case report of chronic subdural hematoma. Chin Med J (Taipei) 1994; 54: 141-4.

14 Defalque RJ, Musunuru VS. Diseases of the nervous system. In: Stoelting RK, Dierdorg SF (Eds.). Anesthesia and Co-existing Disease. New York: Churchill Livingstone, 1983: 275. 